\title{
PEMBELAJARAN DI ERA COVID-19
}

\author{
Dailami \\ 1810128110006 \\ Prodi Pendidikan IPS FKIP universitas Lambung Mangkurat Banjarmasin \\ E-mail : dailami241@gmail.com
}

\begin{abstract}
Abstrak
Pada masa pademi Covid-19 sekarang menuntut kita agar bekerja dari rumah, work from home (WFH), termasuk belajar dan beribadah di rumah bahkan belanja dari rumah. Dalam situasi tersebut maka teknologi berperan penting, termasuk dalam bidang pendidikan. Pembelajaran saat ini dilakukan secara daring (dalam jaringan). Hal tersebut dianggap solusi yang terbaik untuk mencegah penyebaran virus Covid-19. Pembelajaran daring juga di terapkan kepada mahasiswa Pendidikan IPS FKIP ULM. Aplikasi yang sering digunakan diantaranya google meet, zoom, google classroom, Edmodo dan Elearning. Walau pembelajaran daring dianggap bagus, dianggap lebih fleksibel tempat dan waktu, tapi tidak bisa kita pungkiri juga bahwa dari pembelajaran daring tersebut ada beberapa kendala yang dirasakan mahasiswa. Contohnya tidak ada sinyal, Kouta internet boros dan penjelasan dosen tidak terlalu jelas. Minat mahasiswa dalam belajar daring semakin lama semakin menurun, sehingga mengharuskan dosen untuk mencari strategi baru dalam mengajar. Salah satunya adalah dengan menulis artikel yang berkaitan dengan Covid-19 di lihat dari aspek ilmu-ilmu sosial.
\end{abstract}

Kata Kunci : Pembelajaran, Peserta didik, Covid-19

\section{PENDAHULUAN}

Pada saat ini masyarakat dunia sedang dilanda sebuah musibah yaitu penyebaran virus Covid-19 yang menimbulkan banyak korban jiwa. Hal itu membuat masyarakat dunia khawatir dalam beraktivitas diluar rumah karena takut terpapar virus Covid-19 termasuk Indonesia. Oleh karena itu pemerintah mengeluarkan kebijakan untuk masyarakat tetap berada di rumah serta mematuhi segala protkol kesehatan yang dibuat pemerintah. COVID-19 atau Corona Virus Deaseases mulai mewabah di Wuhan China pada Desember 2019. Penyebarannya semakin masif ke beberapa negara pada awal 2020 dan masuk ke Indonesia pada Maret 2020. Pada tanggal 11 Maret 2020 WHO menetapkan wabah ini sebagai pandemik global. Hingga saat ini, secara global korban meninggal telah mencapai 316.860 orang dan di Indonesia telah menembus hingga angka 1.192 orang, dari data per 18 Mei 2020 (Syaharuddin, S., 2020). 
Hal ini berdampak pada berbagai bidang, termasuk dalam pendidikan. Untuk mengurangi resiko penularan virus corona, diantara langkah prefentif yang telah diambil pemerintah adalah menghimbau agar bekerja dari rumah, work from home (WFH), termasuk belajar dan beribadah di rumah bahkan belanja dari rumah. Langkah ini bertujuan untuk mendukung kebijakan selanjutnya yakni social and fisical distancing (Syaharuddin, S., 2020). Untuk mengatasi kekhawatiran orang tua, peserta didik dan guru maka pemerintah mengeluarkan Surat Edaran Kemendikbud No 15 Tahun 2020 tanggal 18 Mei 2020 mengenai Pedoman penyelenggaraan belajar dari rumah semasa darurat Covid-19.

Teknologi saat ini sangat berperan dalam segala aspek kehidupan khususnya pendidikan. Pembelajaran secara daring (dalam jaringan) atau online telah menggeser pembelajaran secara tatap muka atau konvensional. Secara tidak langsung pada saat ini kita harus bisa beradaptasi dengan keadaan yang menuntut kita memanfaatkan teknologi untuk belajar. Banyak manfaat yang didapatkan dalam pembelajaran daring, salah satunya pembelajaran bisa dilaksanakan pada waktu kapan pun dan dimana pun peserta didik atau mahasiswa itu berada. Tidak seperti pembelajaran secara konvensional yang mengharuskan kita belajar di dalam ruangan atau dikelas.

Pembelajaran daring menjadi sebuah solusi untuk mengatasi masalah yang dihadapi oleh sekolah atau perguruan tinggi dalam sistem pendidikan. Dengan memberikan penjelasan dan pembelajaran yang baik dan jelas, para mahasiswa dapat melaksanakan pembelajaran daring dengan efisien dan lebih maksimal . Walau tidak bisa melakukan pembelajaran secara tatap muka langsung, tapi diharapkan dalam pembelajaran daring ini bisa membuat mahasiswa lebih bersikap mandiri dalam belajar. Walaupun pembelajaran daring ini memiliki beberapa hal positif, tetapi ada beberapa kendala atau hambatan yang perlu di perhatikan. Misalnya lemahnya sinyal di wilayah tertentu tempat mahasiswa itu berada, terbatasnya kouta internet yang cepat habis, serta kurangnya pengetahuan dalam menggunakan aplikasi dalam mendukung pembelajaran.

Penggunaan teknologi seperti aplikasi dalam mendukung pembelajaran sangat penting dipelajari agar pembelajaran bisa berjalan lancar. Dalam pembelajaran daring ada beberapa aplikasi yang sering dipakai untuk menunjang pembelajaran, seperti Google Classroom, Edmodo, dan laman pembelajaran daring kampus E-learning. Selain itu ada juga bisa juga melalui aplikasi pesan instan seperti WhatsApp atau aplikasi lain yang 
memberikan kemudahan pembelajaran lewat vedio seperti Zoom dan Google meet. Hal tersebut hampir dilakukan oleh setiap pendidik, khususnya dosen di Prodi Pendidikan IPS FKIP ULM. Selama pandemi sekarang pembelajaran prodi pendidikan IPS dilakukan secara daring melalui beberapa aplikasi, yaitu Google meet, google classroom dan Elearning.

\section{PEMBAHASAN}

\section{Minat Mahasiswa terhadap Pembelajaran Daring}

Ketika COVID-19 mewabah hingga ke Indonesia dan memuncak pada Maret 2020, pemerintah mengeluarkan kebijakan WFH (work from home) agar virus ini tidak menyebar secara massif. Respons dunia pendidikan adalah belajar secara online atau daring. Sekolah dan kampus semua 'diliburkan' alias beralih belajar di kampus ke rumah sebagai konsekuensi kebijakan WFH sehingga social and fisical distancing dapat berjalan untuk mengurangi penyebaran virus (Syaharuddin, S., 2020).

Dengan pengaruh teknologi informasi dan komunikasi yang semakin maju, bisa dikatakan hampir semua mahasiswa memiliki handphone android atau biasa disebut smartphone. Oleh karena itu apabila mahasiswa ada yang tidak mempunyai laptop atau komputer, mereka tetap bisa melaksanakan pembelajaran daring dengan menggunakan smartphone yang mereka miliki. Karena aplikasi yang mendukung pembelajaran daring bisa diinstal pada smartphone.

Dengan pembelajaran daring yang selama ini dilaksanakan, minat mahasiswa pendidikan IPS FKIP ULM dalam pembelajaran daring cukup tinggi. Seorang mahasiswa yang memiliki motivasi tinggi mencari ilmu, akan mengikuti pembelajaran dengan baik. Motivasi sebagai daya penggerak individu untuk menimbulkan kelangsungan pembelajaran ke arah yang lebih baik (Rahman, A. M., Mutiani, M., \& Putra, M. A. H., 2019). Mereka mengatakan bahwa pembelajaran daring lebih mudah dalam hal waktu dan tempat. Karena dapat diketahui pembelajaran daring dapat dilakukan kapan saja tidak harus mengikuti jadwal dan bisa dilakukan dimana saja. Dengan adanya pembelajaran daring mahasiswa dan dosen akan lebih mudah dan terbantu dalam melakukan pembelajaran pada saat pandemi sekarang, serta pembelajaran bisa dilakukan pada tempat yang berbeda. Mereka juga ada yang mengatakan pembelajaran daring bisa mengurangi pengeluaran uang untuk anak perantauan yang biasanya dikeluarkan untuk makan, bensin 
motor, bayar kost dan lainnya berkaitan dengan tugas kampus. Walaupun begitu dari beberapa keuntungan tadi ada kendala yang lain yaitu Kouta internet menjadi semakin boros tidak seperti biasanya.

Beberapa mahasiswa yang kurang minat dan tidak berminat juga mengungkapkan keluhan mereka terhadap pembelajaran daring. Alasannya karena tidak adanya sinyal di daerah mereka dan borosnya Kouta internet. Kendala lainnya yang menjadi keluhan mahasiswa yaitu seringnya sinyal yang sering naik turun sehingga penjelasan dosen ataupun presentasi dari mahasiswa lain menjadi sulit dipahami, selain itu juga karena gangguan jaringan aplikasi pendukung pembelajaran daring menjadi terganggu, seperti sering aplikasi tertutup sendiri, aplikasi tidak bisa dijalankan dan lainnya. Dari penjelasan di atas bisa kita lihat bahwa walaupun ada beberapa mahasiswa yang berminat dan antusias terhadap pembelajaran daring tetapi sebagian lagi ada yang tidak minat karena merasa banyak kendala. Hal itu dapat kita sadari bahwa kita tidak sendiri tetapi ada orang lain yang berbeda pemikiran dengan kita, oleh karena itu penting bagi kita untuk belajar memahami orang lain. Sesuai dengan Pendidikan IPS mampu membentuk peserta didik untuk menyadari dirinya sebagai bagian dari warga negara dunia yang harus memahami orang lain dalam hidupnya. Tentunya hal yang dimaksud dapat diimplementasikan melalui konsepsi manusia sebagai makhluk individu dan sosial yang melekat dalam kehidupan sehari-hari (Subiyakto, B., \& Mutiani, M., 2019).

\section{Penerapan Pembelajaran Daring}

Penerapan pembelajaran daring yang menggunakan aplikasi pendukung dirasakan menjadi suatu kemudahan dalam mengatasi pembelajaran dalam masa pandemi sekarang. Mahasiswa tidak perlu lagi datang ke kampus dan masuk kelas untuk belajar, tetapi sekarang mereka hanya cukup melakukan pembelajaran di rumah masing-masing menggunakan smartphone atau laptop mereka untuk melakukan pembelajaran daring atau online. Pelaksanaan aktivitas belajar di rumah dengan media daring menuntut mahasiswa menguasai media yang beragam. Dengan keberanekaragaman media daring yang sebelumnya belum pernah menggunakannya, mahasiswa dituntut untuk menguasainya.

Pembelajaran daring pada saat ini bila dilakukan dengan benar akan kreativitas berpikir mahasiswa dalam mempelajari pengetahuan baru. Sesuai dengan tori kognitif mendefinisikan pembelajaran sebagai proses belajar yang dibangun oleh guru untuk 
mengembangkan kreativitas berpikir dan dapat meningkatkan kemampuan peserta didik mengkonstruksi pengetahuan baru sebagai upaya meningkatkan penguasaan yang baik terhadap materi pelajaran (Syaharuddin, S., \& Mutiani, M., 2020).

Dengan melakukan pembelajaran secara daring yang banyak memberikan kemudahan untuk mahasiswa dan dosen, tetapi nyatanya masih ada beberapa kesulitan yang dialami. Ada beberapa yang mengatakan materi perkuliahan sangat sulit dipahami dibandingkan dengan materi yang di sampaikan pada pembelajaran secara tatap muka atau konvensional. Selain itu dalam pembelajaran daring dosen dan mahasiswa ada yang belum terlalu bisa memakai aplikasi untuk pembelajaran daring.

Kalau hal ini kita kaitkan dengan ilmu sosial, pada masa pandemi sekarang bisa menjadi suatu sejarah baru yang dapat dipelajari dimasa depan nanti. Sejarah diartikan bukan sekedar rangkaian peristiwa melainkan lingkaran peristiwa yang terentang dalam lilitan benang gagasan. Sederhana gagasan kemudian ditafsirkan sebagai dasar sebuah tindakan (perilaku) berada di belakang setiap kejadian sehingga peristiwa dianggap penting (Mutiani, M., WARMANSYAH ABBAS, E. R. S. I. S., Syaharuddin, S., \& Susanto, H., 2019). Ilmu sejarah diperlukan oleh manusia untuk penelitian dan pembelajaran bagi keberlangsungan kehidupan manusia dimuka bumi. Pembelajaran sejarah merupakan bagian dari pengajaran dan pendidikan pada persekolahan (Mutiani, M., WARMANSYAH ABBAS, E. R. S. I. S., Syaharuddin, S., \& Susanto, H., 2019).

\section{Menulis dalam masa pandemi Covid-19}

Pada masa pembelajaran daring, awalnya semua mahasiswa dan dosen mengikuti pembelajaran dengan penuh antusias, menyenangkan dan bersemangat. Hal tersebut karena selama bertahun-tahun pendidikan di Indonesia baru sekarang pembelajaran daring dilakukan. Namun hal itu tidak terjadi untuk bulan-bulan berikutnya. Memasuki bulan ketiga, semangat dalam berdiskusi mulai kendor, namun kadang grafik semangat belajar naik seiring penggunaan metode baru, seperti studi kasus. Karena sedang pandemi Covid-19, maka dosen memberikan tugas membuat artikel Covid-19 dengan berbagai sudut pandang dalam ilmu-ilmu sosial (Syaharuddin, S., 2020). Sebagai seorang dosen atau guru harus memiliki strategi yang bisa diterapkan untuk membuat peserta didik tidak bosan dalam pembelajaran, tetapi harus sesuai dengan peran guru atau dosen itu sendiri.Guru mempunyai peranan yang amat strategis dan urgen dalam keseluruhan upaya 
pendidikan. Hampir semua usaha pembaharuan di bidang kurikulum dan penerapan metode mengajar guru, pada akhirnya tergantung pada guru itu sendiri. Guru ialah orang yang merencanakan, dan melaksanakan proses pembelajaran, menilai serta membimbing peserta didik untuk meraih cita-cita dan memiliki budi pekerti (Subiyakto, B., \& Akmal, H., 2020). Satu di antara empat kompetensi seorang dosen, kompetensi pedagogik harus dikembangkan dari waktu ke waktu. Kompetensi pedagogik merupakan kemampuan dosen dalam merencanakan, melaksanakan, mengevaluasi, dan menindak lanjuti hasil PEMBELAJARAN agar menjadi lebih baik (Rahman, A. M., Mutiani, M., \& Putra, M. A. H., 2019). Menurut Suwarma Al Muchtar (2015) mengemukakan bahwa sumber daya belajar perlu dilakukan transformasi sikap dan perilaku dari kebiasaan menggunakan sumber daya belajar terbatas pada buku pelajaran sebagai satu-satunya sumber kepada penggunaan aneka media, dari kebiasaan tatap muka di kelas kearah optimalisasi sumber daya belajar yang ada dilingkungan sekolah dan peserta didik, perlu dibudayakan menjadikan masyarakat sebagai sumber media belajar (ABBAS, E. W., Hidayat Putra, M. A., \& Noor Handy, M. R., 2019).

Penerapan pembelajaran dengan menulis sebuah artikel tersebut menjadi hal baru bagi mahasiswa, sehingga keseharian mereka sudah mulai terbiasa untuk menulis. Menulis itu belajar, membelajarkan diri (Abbas, E. W., 2020). Terkadang banyak mahasiswa yang marasa kesulitan dalam menulis, sehingga hal tersebut yang membuat mahasiswa malas untuk menulis. Padahal bila kita pelajari dengan seksama menulis itu mudah, karena di setiap keseharian kita selalu mendapat semua informasi lewat panca Indra, dan semua informasi itu terkumpul di tulis di otak. Semua orang yang menggunakan pancaindranya adalah penulis (WARMANSYAH ABBAS, E. R. S. I. S.,2020). tulisan di otak yang disimpan di memori dan diolah, manakala "dituangkan", jadilah tulisan. Menulis berarti menginput informasi (menulis di otak), memproses informasi (menulis di otak), dan menyalinnya menjadi tulisan yang secara umum diistilahkan menulis (WARMANSYAH ABBAS, E. R. S. I. S.,2020). Kebiasaan menulis akan terbangun dengan keyakinan kita sendiri. Pada masa pandemi sekarang pastinya kita memiliki waktu yang luang sehingga hal tersebut seharusnya bisa kita manfaatkan untuk menulis.

\section{SIMPULAN}


Pada tanggal 11 Maret 2020 WHO menetapkan wabah virus Covid-19 sebagai pandemik global. Hal ini berdampak pada berbagai bidang, termasuk dalam pendidikan. Untuk mengurangi resiko penularan virus corona, diantara langkah prefentif yang telah diambil pemerintah adalah menghimbau agar bekerja dari rumah, work from home (WFH), termasuk belajar dan beribadah di rumah bahkan belanja dari rumah. Langkah ini bertujuan untuk mendukung kebijakan selanjutnya yakni social and fisical distancing.

Teknologi informasi dan komunikasi pada saat ini sangat berperan penting dalam segala aspek kehidupan khususnya pendidikan. Pembelajaran secara daring (dalam jaringan) atau online telah menggeser pembelajaran secara tatap muka atau konvensional. Banyak manfaat yang didapatkan dalam pembelajaran daring, salahsatunya pembelajaran daring bisa dilakukan pada waktu kapanpun dan pada tempat dimana pun..

Dengan pembelajaran daring yang selama ini dilaksanakan, minat mahasiswa pendidikan IPS FKIP ULM dalam pembelajaran daring cukup tinggi. Seorang mahasiswa yang memiliki motivasi tinggi mencari ilmu, akan mengikuti pembelajaran dengan baik. Motivasi sebagai daya penggerak individu untuk menimbulkan kelangsungan pembelajaran ke arah yang lebih baik. Beberapa mahasiswa yang kurang minat dan tidak berminat juga mengungkapkan keluhan mereka terhadap pembelajaran daring. Alasannya karena tidak adanya sinyal di daerah mereka dan borosnya Kouta internet.

Satu di antara empat kompetensi seorang dosen, kompetensi pedagogik harus dikembangkan dari waktu ke waktu. Kompetensi pedagogik merupakan kemampuan dosen dalam merencanakan, melaksanakan, mengevaluasi, dan menindak lanjuti hasil pembelajaran agar menjadi lebih baik. Penerapan pembelajaran dengan menulis sebuah artikel tersebut menjadi hal baru bagi mahasiswa, sehingga keseharian mereka sudah mulai terbiasa untuk menulis. Menulis itu belajar, membelajarkan diri.

\section{DAFTAR PUSTAKA}

Abbas, E. W. (2020). Menulis Artikel Jurnal. Menulis Artikel Jurnal.

ABBAS, E. W., Hidayat Putra, M. A., \& Noor Handy, M. R. (2019). Laporan Penelitian: PEMANFAATAN EKOWISATA SUNGAI MARTAPURA KOTA BANJARMASIN SEBAGAI SUMBER BELAJAR IPS.

Mutiani, M., WARMANSYAH ABBAS, E. R. S. I. S., Syaharuddin, S., \& Susanto, H. (2019). Penerapan Transcript Based Lesson Analyses (TBLA) Sebagai Upaya Peningkatan Pembelajaran Sejarah Di Sma Negeri 7 Banjarmasin.

Rahman, A. M., Mutiani, M., \& Putra, M. A. H. (2019). Pengaruh kompetensi pedagogik dosen terhadap motivasi belajar mahasiswa pendidikan IPS. Jurnal Darussalam: Jurnal Pendidikan, Komunikasi dan Pemikiran Hukum Islam, 10(2), 375-387. 
Syaharuddin, S. (2020). Menimbang Peran Teknologi dan Guru dalam Pembelajaran di Era COVID-19. Menimbang Peran Teknologi dan Guru dalam Pembelajaran di Era COVID-19.

Syaharuddin, S. (2020). PEMBELAJARAN MASA PANDEMI: DARI KONVENSIONAL KE DARING. PEMBELAJARAN MASA PANDEMI: DARI KONVENSIONAL KE DARING.

Subiyakto, B., \& Akmal, H. (2020). Profesi Keguruan.

Subiyakto, B., \& Mutiani, M. (2019). Internalisasi nilai pendidikan melalui aktivitas masyarakat sebagai sumber belajar ilmu pengetahuan sosial. Khazanah: Jurnal Studi Islam dan Humaniora, 17(1), 137-166.

Syaharuddin, S., \& Mutiani, M. (2020). STRATEGI PEMBELAJARAN IPS: Konsep dan Aplikasi.

WARMANSYAH ABBAS, E. R. S. I. S. (2020). Menulis di Era Covid-19: Memanage Trauma Psikologis Menghindari Psikosomatis. Menulis di Era Covid-19: Memanage Trauma Psikologis Menghindari Psikosomatis. 